Ann. rheum. Dis. (1958), 17, 114.

\title{
RHEUMATOID ARTHRITIS AND SYSTEMIC LUPUS ERYTHEMATOSUS
}

\author{
BY \\ MARY BATEMAN, J. M. MALINS, AND M. J. MEYNELL \\ From the General Hospital, Birmingham
}

Kaposi (1872) first noticed the joint pains of lupus erythematosus and remarked that they might precede the acute stage of the disease. Osler (1904) and Jadassohn (1904) indicated the widespread visceral lesions and occasionally chronic nature of lupus erythematosus and referred to the occurrence of arthritis. Reifenstein, Reifenstein, and Reifenstein (1939) reported deforming arthritis indistinguishable from rheumatoid arthritis in three of eighteen cases of systemic lupus erythematosus (S.L.E.). The discovery of the L.E. cell phenomenon by Hargraves, Richmond, and Morton (1948) stimulated a new interest in the disease, which came to be diagnosed much more frequently, as the test appeared to be highly specific for S.L.E. The clinical picture thus acquired a new definition, though the evolution of the lesions was by now being modified by the use of cortisone. From 1953, reviews of large series of cases began to appear (Dubois, 1953; Ross and Wells, 1953; Harvey, Shulman, Tumulty, Conley, and Schoenrich, 1954). Dubois especially emphasized the frequency of arthritis as a presenting feature and remarked that "patients may complain of arthralgia with or without joint swelling for many years prior to any other evidence of systemic involvement".

The present paper describes 28 cases presenting the features of chronic rheumatoid arthritis in whom L.E. cells were demonstrated in the peripheral blood.

Clinical Features.-These are shown in Table I (opposite).

The average age at the onset of arthritis was 40 years (range 11 to 64). The longest duration of arthritis at the time of the first positive L.E. cell test was 26 years, but the longest period of observation from the first positive test is only 4 years. The arthritis in every case was typically rheumatoid, involving the hands, wrists, elbows, shoulders, ankles, and knees in every case; in fifteen cases the jaw joints and in six the hips were affected. In 22 patients the disease was advanced, with ulnar deviation of the hands, disorganization of the wrists, and gross muscle wasting. In the remaining six cases, the fusiform swelling of the interphalangeal joints and effusions into the wrist, ankle, and knee joints were obvious. Subcutaneous nodules were constantly present in fifteen cases, of which four showed the characteristic necrobiotic histology. The systemic lesions listed in Table I occurred in fifteen patients, but in the other thirteen the arthritis was the sole manifestation throughout, and at the time of writing only two of the 26 surviving patients (Cases 8 and 24) show evidence of an active systemic lesion, in each case a progressive nephritis with renal failure. The laboratory findings are summarized in Table II (overleaf).

Skin Lesions.-Only three patients showed the classical erythema of butterfly distribution on the face. Recurrent urticaria was reported by two patients. In four patients (Cases 8, 9, 12, and 24), chronic ulceration of the lower limb of a peculiar character occurred. A painful nodular swelling in the skin broke down to form a shallow ulcer in which granulation tissue formed quickly. The area varied from 2 to $12^{\prime \prime}$ in diameter, and was on the thigh, leg, or dorsum of the foot. Healing was slow but complete and not obviously influenced by any form of treatment. Cases 8 and 12 have had one episode, each with two areas of ulceration, but Case 9 has had four separate attacks. In all four patients the arthritis was severe with gross deformity. These skin lesions are evidently the same as those recorded by Allison and Bettley (1957).

Fatal Cases.-Case 27, with chronic rheumatoid arthritis of 12 years' duration, was admitted to hospital with severe purpura, associated with thrombocytopenia, which responded fully to splenectomy after cortisone had failed to influence the platelet count. She died 6 months later from carcinomatosis secondary to a carcinoma of the rectum; the findings were confirmed at autopsy which revealed no characteristic lesions of S.L.E. 
TABLE I

CLINICAL FEATURES

\begin{tabular}{|c|c|c|c|c|c|}
\hline Case No. & $\begin{array}{c}\text { Age at Onset } \\
\text { of Arthritis } \\
\text { (yrs) }\end{array}$ & $\begin{array}{l}\text { Duration of } \\
\text { Arthritis at } \\
\text { Discovery of } \\
\text { L.E. Cells } \\
\text { (yrs) }\end{array}$ & $\begin{array}{l}\text { Systemic Manifestations } \\
\text { (yrs after onset of arthritis) }\end{array}$ & $\underset{\text { Skin }}{\text { Manifestations }}$ & Nodules \\
\hline 1 & 37 & 7 & Pleurisy $(+7)$ & None & 0 \\
\hline 2 & 32 & 11 & Pericarditis $(+11)$ & None & 0 \\
\hline 3 & 58 & 0 & $\begin{array}{l}\text { Central retinal } \\
\text { vein thrombosis }(+2)\end{array}$ & None & 0 \\
\hline 4 & 28 & 4 & None & None & + \\
\hline 5 & 16 & 7 & None & Urticaria & + \\
\hline 6 & 47 & 4 & Pleurisy $(+3)$ & None & 0 \\
\hline 7 & 11 & 26 & Pericarditis $(+7)$ & Urticaria & 0 \\
\hline 8 & 39 & 14 & Nephritis $(+8)$ & Leg ulcers & + \\
\hline 9 & 45 & 8 & Pleurisy $(+9)$ & Leg ulcers & + \\
\hline 10 & 35 & 20 & None & None & 0 \\
\hline 11 & 52 & 13 & None & None & 0 \\
\hline 12 & 64 & 7 & Punctate keratitis $(+6)$ & Leg ulcers & 0 \\
\hline 13 & 47 & 6 & None & None & + \\
\hline 14 & 48 & 7 & None & None & + \\
\hline 15 & 33 & 11 & None & None & + \\
\hline 16 & 42 & 7 & Staphylococcal septicaemia $(+3)$ & None & + \\
\hline 17 & 28 & 3 & Pericarditis (0) & Butterfly erythema & + \\
\hline 18 & 39 & 16 & None & None & + \\
\hline 19 & 26 & 5 & None & None & $\mathbf{0}$ \\
\hline 20 & 44 & 10 & None & None & 0 \\
\hline 21 & 38 & 8 & None & None & 0 \\
\hline 22 & 55 & 14 & Nephritis $(+14)$ & None & + \\
\hline 23 & 58 & 5 & None & None & 0 \\
\hline 24 & 51 & 22 & None & Leg ulcers & + \\
\hline 25 & 40 & 6 & Pericarditis $(+5)$ & None & + \\
\hline 26 & 30 & 24 & Pleurisy $(+24)$ & Butterfly erythema & + \\
\hline 27 & 57 & 12 & $\begin{array}{l}\text { Thrombocytopenia }(+12) \\
\text { Carcinoma of rectum }\end{array}$ & None & 0 \\
\hline 28 & 30 & 10 & Ovarian carcinoma & Butterfly erythema & + \\
\hline
\end{tabular}

Case 28, who had had severe rheumatoid arthritis for 11 years, developed ascites from a fixed ovarian growth and responded for 3 months to irradiation. She died in an institution but no autopsy was performed.

Treatment.-Twenty of the patients were given one or more 1-g. courses of Myocrisin. Ten considered that they had benefited, at least from the first course, and ten thought the treatment of no value. Four developed skin rashes and albuminuria attributable to the treatment.
25 patients were treated with oral cortisone, the daily dose not exceeding $100 \mathrm{mg}$; five reported striking benefit to the arthritis, fourteen slight improvement, and six no change.

L.E. Cell Test.-All these patients gave a positive result on at least two occasions. In eighteen of them the test has at some later time been negative. 23 of the 28 cases had never received cortisone when the first positive result was obtained.

The method used was essentially that of Magath and Winkle (1952). $10 \mathrm{ml}$. blood are collected in a 
TABLE II

LABORATORY FINDINGS

\begin{tabular}{|c|c|c|c|c|c|c|c|c|}
\hline \multirow{3}{*}{ Case No. } & \multirow{3}{*}{$\begin{array}{c}\text { Highest and } \\
\text { Lowest } \\
\text { Erythrocyte } \\
\text { Sedimentation } \\
\text { Rate }\end{array}$} & \multirow{3}{*}{$\begin{array}{c}\text { Lowest } \\
\text { Haemo- } \\
\text { globin }\end{array}$} & \multirow{3}{*}{$\begin{array}{l}\text { Direct } \\
\text { Coombs' } \\
\text { Test }\end{array}$} & \multirow{3}{*}{$\begin{array}{c}\text { Sheep Cell } \\
\text { Agglutination } \\
\text { Test }\end{array}$} & \multicolumn{4}{|c|}{ Serum Proteins } \\
\hline & & & & & \multirow{2}{*}{ Albumin } & \multicolumn{3}{|c|}{ Globulin } \\
\hline & & & & & & $\alpha_{1}$ & $\alpha_{2}$ & $\gamma$ \\
\hline 1 & $148 / 7$ & 42 & Pos. & - & $2 \cdot 5$ & $2 \cdot 75$ & 0.56 & $1 \cdot 5$ \\
\hline 2 & $78 / 26$ & 78 & Neg. & - & $4 \cdot 0$ & $3 \cdot 62$ & 0.58 & $1 \cdot 74$ \\
\hline 3 & $104 / 26$ & 82 & Neg. & - & $3 \cdot 42$ & $3 \cdot 68$ & $0 \cdot 58$ & $1 \cdot 88$ \\
\hline 4 & $6 / 1$ & 72 & Neg. & Neg. & $4 \cdot 13$ & $3 \cdot 89$ & 0.61 & $1 \cdot 85$ \\
\hline 5 & $108 / 35$ & 66 & Pos. & $+t+$ & $2 \cdot 9$ & $4 \cdot 4$ & 0.6 & $2 \cdot 3$ \\
\hline 6 & $84 / 44$ & 86 & - & - & $3 \cdot 76$ & $4 \cdot 24$ & 0.58 & $2 \cdot 61$ \\
\hline 7 & 64 & 91 & Neg. & - & $4 \cdot 7$ & $4 \cdot 05$ & $0 \cdot 52$ & $2 \cdot 68$ \\
\hline 8 & $52 / 10$ & 62 & Neg. & $+t+$ & $2 \cdot 8$ & $3 \cdot 16$ & $0 \cdot 57$ & $1 \cdot 55$ \\
\hline 9 & $68 / 62$ & 66 & Neg. & +++ & $3 \cdot 66$ & $3 \cdot 51$ & $0 \cdot 56$ & $1 \cdot 87$ \\
\hline 10 & $48 / 19$ & 81 & Neg. & $++t$ & $2 \cdot 8$ & $4 \cdot 1$ & 0.8 & $1 \cdot 8$ \\
\hline 11 & $43 / 11$ & 67 & Neg. & +++ & $3 \cdot 4$ & $3 \cdot 8$ & 0.7 & $1 \cdot 5$ \\
\hline 12 & 19 & 81 & Neg. & $++t$ & $2 \cdot 0$ & $4 \cdot 4$ & 0.7 & $2 \cdot 2$ \\
\hline 13 & $95 / 37$ & 78 & Pos. & +++ & $2 \cdot 8$ & $5 \cdot 0$ & 0.9 & $2 \cdot 5$ \\
\hline 14 & $84 / 35$ & 62 & Neg. & $++t$ & $3 \cdot 0$ & $4 \cdot 0$ & 0.6 & $2 \cdot 6$ \\
\hline 15 & $48 / 2$ & 78 & Neg. & $+t+$ & $3 \cdot 3$ & $3 \cdot 8$ & 0.6 & $2 \cdot 2$ \\
\hline 16 & 57 & 90 & - & - & - & - & - & - \\
\hline 17 & $25 / 11$ & 62 & - & - & $3 \cdot 9$ & $3 \cdot 0$ & - & - \\
\hline 18 & 66 & 86 & Neg. & $++t$ & $3 \cdot 4$ & $4 \cdot 3$ & 0.9 & $2 \cdot 4$ \\
\hline 19 & $12 / 7$ & 82 & Neg. & ++ & $2 \cdot 8$ & $4 \cdot 3$ & 0.8 & $2 \cdot 1$ \\
\hline 20 & $32 / 18$ & 86 & Neg. & + & $3 \cdot 3$ & $4 \cdot 5$ & 0.8 & $2 \cdot 3$ \\
\hline 21 & $110 / 18$ & 74 & Neg. & $+t+$ & $2 \cdot 4$ & $4 \cdot 4$ & $1 \cdot 5$ & $2 \cdot 0$ \\
\hline 22 & $102 / 83$ & 75 & Neg. & - & $1 \cdot 3$ & $3 \cdot 8$ & $1 \cdot 0$ & 0.9 \\
\hline 23 & $73 / 40$ & 80 & - & $+t+$ & $3 \cdot 4$ & $4 \cdot 5$ & $1 \cdot 0$ & $2 \cdot 4$ \\
\hline 24 & $150 / 74$ & 42 & - & - & - & - & - & - \\
\hline 25 & $92 / 18$ & 60 & Neg. & $+1+$ & $3 \cdot 3$ & $4 \cdot 3$ & 0.8 & $2 \cdot 6$ \\
\hline 26 & $51 / 4$ & 96 & - & - & - & - & - & - \\
\hline 27 & 3 & 46 & Neg. & + & $2 \cdot 74$ & $2 \cdot 4$ & - & - \\
\hline 28 & $76 / 64$ & 56 & Neg. & - & $3 \cdot 7$ & $3 \cdot 5$ & - & - \\
\hline
\end{tabular}

dry test tube, allowed to clot, and incubated for $2 \mathrm{hrs}$ at $37^{\circ} \mathrm{C}$. The serum is discarded and the clot is broken up with a glass rod by forcing it through a copper gauze sieve ( 40 strands to the inch) over a Petri dish. The material is pipetted into a Wintrobe tube and centrifuged at 2,000 r.p.m. for 5 minutes. The serum is withdrawn with a Pasteur pipette and discarded. Films are made of the buffy coat and are stained with Jenner Giemsa. About five slides of each preparation are made, and 15 to 20 minutes are spent examining each specimen.

The results of L.E. tests on 337 patients examined at Birmingham General Hospital are listed in
Table III (opposite). The series is not continuous and is not intended to indicate the relative frequency of the diseases included.

\section{Discussion}

The concept of systemic lupus erythematosus as a disease with widespread manifestations not necessarily involving the skin, first suggested by Osler, has been greatly advanced by the discovery of the L.E. cell and the widely-held belief that it is specific for this disease only. Harvey and others (1954) found 79 positive tests in 96 cases of S.L.E. and 
TABLE III

RESULTS OF 337 L.E. CELL TESTS

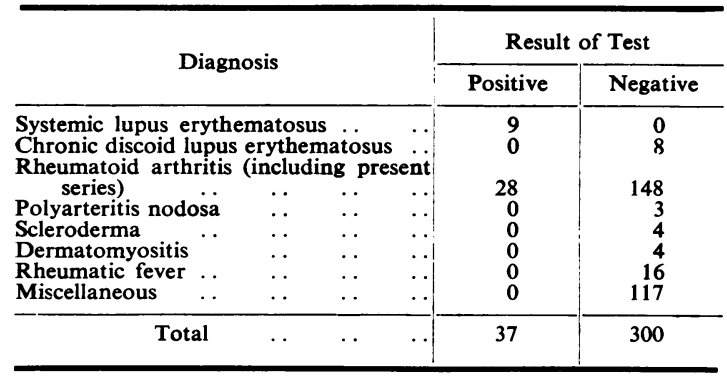

negative results in 553 other patients (including 116 cases of rheumatoid arthritis). Similar findings were recorded by Dubois (1953) and Haserick (1951). Positive tests in patients not considered to have S.L.E. have been reported in haemolytic anaemia (Lee, Michael, and Vural, 1951), miliary tuberculosis (Lee and others, 1951; Jacobs, 1955), rheumatoid arthritis (Slocumb, 1953; Bywaters, 1956; Thomas and Morgan, 1956; Kievits, Goslings, Schuit, and Hijmans, 1956; Ross and Clardy, 1956), chronic hepatitis (Joske and King, 1955, Mackay, Taft, and Cowling, 1956), pernicious anaemia in relapse (Berman, Axelrod, Goodman, and McClaughry, 1950), subacute glomerulonephritis (Parelhoff, 1953), and sensitivity to various agents including hydantoin (Miescher and Delacrétaz, 1953), penicillin (Walsh and Zimmerman, 1953), and hydralazine (Dustan, Taylor, Corcoran, and Page, 1954; Perry and Schroeder, 1954).

In most of these case records there are clinical features which suggest S.L.E. as a background to the presenting diagnosis. In the case of hydralazine sensitivity, the frequency of a clinical picture indistinguishable from S.L.E. must suggest the possibility that the drug may be an aetiological factor in this disease. No doubt some difficulty arises from a static morbid histological approach and an attempt to make a rigid definition of S.L.E. The point of unification of the apparently diverse cases mentioned above is the presence of a serum globulin capable of depolymerizing desoxyribose nucleic acid. If the primary stimulus is sufficiently strong and long-acting, the ultimate result is indistinguishable from S.L.E. whatever the initial mode of presentation. Within this definition we believe that the L.E. cell is specific for the condition S.L.E., always assuming that a sound technique is carefully interpreted.

Rheumatoid arthritis has long been recognized as more than a disease of the joints, so that the title "rheumatoid disease" has been proposed
(Sinclair and Cruickshank, 1956). The fever, rapid wasting, and malaise in acute cases, out of proportion to the severity of the arthritis, are suggestive of systemic disease, as are the subcutaneous nodules and the lesions occurring in muscle and nerve tissue (Freund, Steiner, Leichtentritt, and Price, 1942; Steiner, Freund, Leichtentritt, and Maun, 1946). Lung changes were reported by Ellman and Ball (1948) and specifically "rheumatoid" lesions in the heart have been described by Baggenstoss and Rosenberg (1944). Sokoloff (1953) found evidence of healed idiopathic pericarditis at autopsy seventeen times more often in patients with rheumatoid arthritis than in others, and Thomas and Morgan (1956) reported three cases of pericarditis in rheumatoid arthritis, of which two had L.E. cells in the blood. They did not regard these two patients as cases of S.L.E., and Kievits and others (1956), having found L.E. cells in 17 per cent. of 488 cases of rheumatoid arthritis, confined their observations to the difference in clinical features between the group with L.E. cells and that without them. The former showed a higher frequency of splenomegaly, disease of the lower respiratory tract, anaemia, and false positive serological tests for syphilis. Ross and Clardy (1956) analysed 91 cases of "rheumatoidlike" arthritis, of which eighteen had a positive L.E. cell test and revealed a considerably higher incidence of involvement of other systems than control groups with negative L.E. tests. Fifteen of our 28 patients had systemic lesions at some time in the course of their arthritis, in every instance compatible with a diagnosis of S.L.E. The remaining thirteen patients at no time had systemic manifestations. The average duration of arthritis in this group was $10 \cdot 3$ years and the greatest duration 22 years. The suggestion of S.L.E. would never have been made if L.E. cells had not been discovered on routine testing, as the whole clinical course was that of slowly advancing arthritis. Apart from the episodes of subacute illness, the group with systemic lesions has presented the same chronic picture. Case 7, for example, had fever and pericarditis 7 years after the onset of rheumatoid arthritis, which had been diagnosed as Still's disease at Great Ormond Street Hospital, but for the 19 years since that illness she had had no systemic disorder.

One cannot fail to be impressed by the tentative or negative conclusions of those writers who have found L.E. cells in cases which appeared to have classical rheumatoid arthritis. Thus Ross and Clardy (1956), who defined their cases with reference to the classification of the American Rheumatism Association (Steinbrocker, Traeger, and Batterman, 1949), still refer to "rheumatoid-like" arthritis and 
so leave the significance of the positive L.E. test quite open. The same point is demonstrated in the admirable review of S.L.E. by Harvey and others (1954): on p. 319 it is stated that the arthritis in 28 of 95 patients with S.L.E. was described as typical of rheumatoid arthritis, while on p. 377 a Table records that 116 cases of rheumatoid arthritis were examined for L.E. cells without one positive result.

We may reasonably ask whether it is necessary to distinguish rheumatoid arthritis from S.L.E. Do these patients have S.L.E. with predominantly arthritic manifestations, or are they cases of rheumatoid arthritis with coincidental S.L.E., or of rheumatoid arthritis with unusual antibody formation giving rise to false positive L.E. tests? It seems to us best to regard them as cases of S.L.E. presenting as rheumatoid arthritis.

The further question, whether it is still necessary to consider rheumatoid arthritis a specific disease entity, cannot be answered here. The majority of cases of rheumatoid arthritis do not display visceral lesions suggestive of S.L.E. or L.E. cells in the blood, but this does not rule out the possibility that their condition represents a very chronic form of S.L.E. capable at times of becoming acute, though in many instances pursuing a chronic course throughout. Perhaps, then, rheumatoid arthritis will in the end be engulfed by the expanding empire of S.L.E., but, for clinical purposes at least, it remains a sufficiently distinct entity at present.

\section{Summary}

28 cases of chronic rheumatoid arthritis with L.E. cells in the peripheral blood are reported. Systemic lesions suggestive of lupus erythematosus occurred in fifteen, and in three there was characteristic ulceration of the legs, but in thirteen arthritis was the only symptom. The significance of the L.E. cell test is discussed. The cases are considered to represent systemic lupus erythematosus with rheumatoid manifestations.

We wish to thank Drs. W. T. Cooke, W. C. Smallwood, B. C. Tate, and A. G. W. Whitfield for allowing us access to their patients.

\section{REFERENCES}

Allison, J. H., and Bettley, F. R. (1957). Lancet, 1, 288.

Baggenstoss, A. H., and Rosenberg, E. F. (1944). "Rheumatoid lesions in the heart." Arch. Path. (Chicago), 37, 54.

Berman, L., Axelrod, A. R., Goodman, H. L., and McClaughry, R. I. (1950). Amer. J. clin. Path., 20, 403.

Bywaters, E. G. L. (1956). Proc, roy. Soc. Med., 49, 287.

Dubois, E. L. (1953). Ann. intern. Med., 38, 1265.
Dustan, H. P., Taylor, R. D., Corcoran, A. C., and Page, I. H. (1954). J. Amer. med. Ass., 154, 23.

Ellman, P., and Bali, R. E. (1948). Brit. med. J., 2, 816

Freund, H. A., Steiner, G., Leichtentritt, B., and Price, A. E. (1942) J. Lab. clin. Med., $27,1256$.

Hargraves, M. M., Richmond, H., and Morton, R. (1948). Proc. Mayo Clin., 23, 25.

Harvey, A. M., Shulman, L. E., Tumulty, P. A., Conley, C. L., and Schoenrich, E. H. (1954). Medicine (Baltimore), 33, 291 .

Haserick, J. R. (1951). Amer. med. Ass., 146, 16.

Jacobs, A. G. (1955). Ann. intern. Med., 42, 1097.

Jadassohn, J. (1904). In "Handbuch der Hautkrankheiten", vol. 3 Jadassohn, J. (1904). In
p. 298 . Vienna.

Joske, R. A., and King, W. E. (1955). Lancet, 2, 477.

Kaposi, M. K. (1872). Arch. Derm. Syph. (Wien, Prag.), 4, 36.

Kievits, J. H., Goslings, J., Schuit, H. R. E., and Hijmans, W. (1956). Annals of the Rheumatic Diseases, 15, 211.

Lee, S. L., Michael, S. R., and Vural, I. L. (1951). Amer. J. Med.,

Mackay, I. R., Taft, L. I., and Cowling, D. C. (1956). Lancet, 2,

Magath, T. B., and Winkle, V. (1952). Amer. J. clin. Path., 22, 586. Miescher, P., and Delacrétaz, J. (1953). Schweiz. med. Wschr., 83, 536.

Osler, W. (1904). Amer. J. med. Sci., 127, 1.

Parelhoff, M. E. (1953). Sinai Hosp. J., 2, 12.

Peıry, H. M., and Schroeder, H. A. (1954). J. Amer. med. Ass., 154,670 .

Reifenstein, E. C., Reifenstein, E. C. Jr., and Reifenstein, G. H. (1939). Arch. intern. Med., 63, 553.

Ross, S. W., and Clardy, E. K. (1956). Sth. med. J., 49, 553.

- and Wells, B. B. (1953). Amer. J. clin. Path., 23, 139.

Sinclair, R. J. G, and Cruickshank, B. (1956). Quart. J. Med., 25 ,

Slocumb, C. H. (1953). Proc. Mayo Clin., 28, 655.

Sokoloff, L. (1953). Amer. Heart J., 45, 635. Steinbrocker, O., Traeger, V. H., and Batterman, R. C. (1949)
J. Amer. med. Ass., 140, 659.

Steiner, G., Freund, H. A., Leichtentritt, B., and Maun, M. E. (1946) Amer. J. Path., 22, 103.

Thomas, A. E., and Morgan, W. R. (1956). Annals of the Rheumatic Diseases, $15,176$.

Walsh, J. R., and Zimmerman, H. J. (1953). Blood. 8, 65.

\section{L'arthrite rhumatismale et le lupus érythémateux généralisé}

RÉSUMÉ

On décrit 28 cas d'arthrite rhumatismale chronique avec des cellules L.E. dans le sang périphérique. Dans 15 cas les lésions générales suggéraient le lupus érythémateux et dans trois autres cas les ulcérations des jambes en portaient le caractère, mais dans 13 cas l'arthrite en était le seul symptôme

On discute l'importance de la recherche des cellules L.E. On croit que les cas décrit ci-dessus représentent le lupus érythémateux généralisé avec manifestations rhumatismales.

\section{La artritis reumatoide y el lupus eritematoso generalizado}

\section{SUMARIO}

Se describen 28 casos de artritis reumatoide crónica con células L.E. en la sangre periférica. En 15 casos las lesiones generales sugirieron el lupus eritematoso y en tres otros casos hubo ulceraciones características de las piernas, pero en 13 casos la artritis fué la única manifestación.

Se discute la importancia de la busqueda de las células L.E. Se considera que los casos descritos aquí representan el lupus eritematoso generalizado con manifestaciones reumáticas. 